\title{
The Effect of Verbal-Linguistic Intelligence and Emotional Intelligence on Academic Achievement of Indonesian EFL Learners
}

\author{
Mujiono and Nakhrowi \\ Language and Literature Faculty, \\ Universitas Kanjuruhan Malang, Indonesia \\ Siti Fatimah \\ Psychology Faculty, \\ Muhammadiyah University of Malang, Indonesia
}

\begin{abstract}
This study was aimed at identifying the effects of verballinguistic intelligence (LI) and emotional intelligence (EI) on the academic achievement of Indonesian EFL Learners. The participants of this study were EFL learners majoring in English Education Department at the Universitas Kanjuruhan Malang, East Java, Indonesia. Two different questionnaires were used to assess learners' LI and EI, while learners' EFL academic achievement referred to the total score of 34 English subjects obtained from Indonesian EFL learners' academic transcripts. To analyse the data, Pearson correlation and multiple regressions were applied. The results revealed that there was a significant correlation between LI and EI, both partially and simultaneously on the academic achievement of Indonesian EFL learners. LI and EI gave $44 \%$ effect on the academic achievement of Indonesian EFL learners. Moreover, it also indicated that LI was a better predictor of their academic achievement than EI.
\end{abstract}

Keywords: Verbal-linguistic intelligence; emotional intelligence; academic achievement; EFL.

\section{Introduction}

The concept of Individual difference (ID) has drawn the attention of educators since it grew out and appeared in the second half of the twentieth century which then led to a renewed view of their educational practice (Rahimi, Sadighi, \& Fard, 2012). The differences between individuals can be described in some ways, which accordingly can categorize each person based on their particularly prominent intelligence types. The most famous theory associated with the individual difference is the theory of Multiple Intelligences (MI) proposed by (Gardner, 1987). He believes that all individuals were born with diverse talents for each of the intelligence, which some of the intelligence is naturally stronger 
than other intelligence. Initially, Gardner's theory identified seven bits of intelligence; verbal-linguistic intelligence, logical-mathematical intelligence, spatial intelligence, musical intelligence, bodily-kinesthetics intelligence, intrapersonal intelligence, and interpersonal intelligence (Gardner, 1987). He worked for a possible other intelligence, i.e. naturalist, spiritual, existential and moral intelligence. Among the seven domains of MI, LI is predicted to be the most appropriate to language learning.

Armstrong (2009) identified LI as the ability to use words effectively, either in speaking or in writing. It also includes the ability to manipulate the structure of a language. Gardner's theory describes that LI as the ability to use the language to address goals, such as the ability to learn a new language (Skourdi \& Rahimi, 2010). Learners do not come to the educational institution with equal intellectual and information processing abilities. They are different from their thinking competences, understanding, abilities, skills, comprehensions, and other aspects of a personality. Although most individuals are capable of learning an L2 to some degree of competence, only some learners are better equipped with the L2 learning task that can achieve the higher or maximum level of the L2 proficiency. They are assumed to be learners with high LI. So, there seems to be a very plausible link between learners' LI and learners' academic achievement in learning English. Learners who have high LI can be assumed they are able to achieve a higher level of English proficiency than learners with low LI. The critical concept of individual differences that can also predict L2 learning success is EI (Tabatabaei \& Jamshidifar, 2013).

In line with the above statement, it can be stated that EI is also a factor that is very influential on learners' success in learning English as a foreign language (EFL) besides LI. It can be argued that to understand the intentions, motivations, and people's pretension to work effectively with others (which are the domain of Emotional Intelligence) are also highly influential on learners' success in learning EFL at the university. Regarding this argument, this study is intended to conduct evidentiary research to examine whether those factors LI and EI affect learners' success in learning EFL. Moreover, many previous studies reported that LI correlates with learners' language skill and knowledge in particular, such as speaking, listening, understanding of lexicon, vocabulary knowledge (Skourdi \& Rahimi, 2010; Parsa \& Jahandar, 2013; Rahimi \& Fard, 2012; Saibani \& Simin, 2014). Other previous studies reported that the EI that closely correlates to learners' success on academics at schools or colleges/universities in general (Nwadinigwe \& Obieke, 2012; Maraichelvi \& Rajan, 2013; Mohzan, Hassan, \& Halil, 2013). However, less study reported the relationship between LI and learners' academic achievement in learning English in general (all skill and knowledge) or the relationship between EI and learners' academic achievement in more specific (in learning English only). Hence, the present study aims to bridge the existing gap between LI, EI and academic achievement of Indonesian EFL learners in learning English. The following research questions guide the discussion of this study:

1) Is there a significant correlation between LI and academic achievement of Indonesian EFL learners? 
2) Is there a significant correlation between EI and academic achievement of Indonesian EFL learners?

3) Is there a significant effect between LI and EI on the academic achievement of Indonesian EFL learners?

\section{Literature Review}

\subsection{Verbal-Linguistic Intelligence ( $\mathrm{Li}$ )}

Linguistic verbal intelligence is one of the nine multiple intelligences (MI) based on s theory of MI developed by Gardner in 1983. Intelligence mostly regarded as a one-single trait and was usually measured based on the one-dimensional concept of intelligence (IQ). Gardner's theory of MI states that this theory does not refer to just one general human intelligence (Abbassi, Hassaskhah, \& Tahriri, 2018). It addresses a group of multiple intelligences, including linguistic (verballinguistic), musical, logical, visual, kinaesthetic, intrapersonal or interpersonal intelligence and naturalist and existential intelligences. Verbal-linguistic intelligence is sometimes also called "word smart" (Armstrong, 2009). It is an intelligence that is usually used when we talk with others, whether in formal speech or informal conversation. We use it when we put our thoughts down on paper, create poetry, or write a letter to a friend. Armstrong, (2009) describes that MI is the capacity of using words effectively, whether orally or in writing. It includes the ability to deal with different aspects of a language as well as to manipulate the syntax or structure of the language, the language, and the pragmatic dimensions or practical uses of language, And use it in different situations (Shero Malo Zebari, Ali Ahmed Allo, \& Mohammedzadeh, 2018).

Halil (2017) describes that the characteristics of people who have the verballinguistic intelligence are sensitive, systematic, good at arguing, etc. They like listening, love reading and writing, easy to spell, love to play the words, good memories about trivial things, and being a reliable public speaker and debater. Therefore, verbal-linguistic intelligence includes language skills of listening, reading effectively, speech, and writing. People who quickly capture oral and written information can be considered to be linguistically intelligent, although they may be not good at talking or writing (producing language). Verballinguistic intelligence has several indicators or unique traits of intelligence. It consists of the ability to think words and to use language to express and appreciate complex meanings. It also involves understanding the order and meaning of words in both speech and writing and how to properly use the language. Gardner's theory states as well as cited in Rahimi, (2014) that Linguistic Intelligence is sensitivity to spoken and written word. Language use can accomplish specific goals, such as the ability to learn new languages.

His pleasure in activities generally characterized people who have high Verballinguistic intelligence. It related to the use of a language, such as reading, writing the essay, poetry, composing aphorisms, playing word games, telling jokes, debating, public speaking, discussions with other people, etc. They also tended to have a good memory for names, dates, and new terms (Armstrong, 2009). In terms of mastery of a new language, if it was linked to the linguistic intelligence's definition by Howard Gardner, people with high Verbal-linguistic 
intelligence generally have a higher capacity than the other people.

Halil (2017) explains that MI is competency to use in terms of words. It is the use of language to express and appreciate the elaborate meaning. It is an essential competence to be achieved by the learners. They are expected to have the capacity to conceptualize in the form of words, to communicate both orally and in the form of writing. They are also demanded to be able to understand the complex meaning.

\subsection{Emotional Intelligence (EI)}

The theory of Emotional intelligence is the first introduced by Meyer and Maludy in the early 1990s (Gharetepeh, Safari, Pashaei, Razaei, \& Bagher Kajbaf, 2015). Daniel Goleman popularized this theory in the mid-90s (Andreani, 2017). Goleman's theory states, as cited in Berenji, (2010) that emotional intelligence can be viewed as abilities to motivate oneself, and persist in the face of frustration. It can control impulses and delay gratification as well as to regulate one`s moods and keep distressed from swapping the ability to think and to emphasize and to hope. Gharetepeh et al., (2015) explains that it is set of linked cognitive and emotional skills having four components such as emotional self-assessment, selfexpression assessment, identification of others' emotions for emotional selfregulation, and the use of emotion to facilitate performance. In various ways, emotional intelligence can be considered as among the most promising of the new constructs emerging in psychological perspectives. It is directed towards improving social adaptation (Kang, 2015). Emotional intelligence describes the distinction of abilities or cognitive capacities. In other words, emotional intelligence has a role to play in the determination of work (Choerudin, 2017).

\subsection{Students' Academic Achievement}

An achievement can be viewed as all an obtaining for an accomplishment of an effort (Vincey, 2016). In terms of education, academic achievement is considered as a proficiency gained or an ability required. It is the amount of knowledge or skills that students have learned. Academic achievement is the educational aim which is achieved by either a student or a teacher over a certain period (Pathak, Tiwari, Patel, \& Kendra, 2018). On other words, they explain that academic achievement can be held as measurable success in the educational field after having instruction. Academic achievement can be defined as the result achieved by learners in the academic field. It is usually measured by standardized tests and represented in a grade. It is dealing with academic achievement grade, a few factors which could influence, such as psychological, social, and learning strategies factors. Psychological aspects encompass the intelligence, students' attitudes on the lesson, and the students' motivation to learn subjects. While social factors involve the social environments of the learners, the learning strategies factor could include teacher's strategies and methods to deliver the materials.

Academic achievement is represented by the grade point average (GPA) (Kuh, Kinzie, Buckley, Bridges, \& Hayek, 2006). They explain that GPA is probably the best predictor of student persistence, degree completion, and graduate school enrolment such as the student success outcomes. Academic achievement is the result of the students' assessment, including cognitive, affective or character 
building, and psychomotor.

\subsection{Related Previous Studies}

Some previous studies about MI in recent years have concerned on the relationship between intelligence and language learning, language proficiency, and academic achievement Saibani \& Simin, (2014) studied the relationship between MI and speaking ability among Iranian EFL learners. The results of this study showed that the dimensions of MI have significant relationships with language skills components. In particular, multiple regression showed that verbal-linguistics, interpersonal, and intrapersonal intelligence were the main predictors of speaking ability in this study. Rahimi et al. (2012) examined the effect of linguistic and EI on the reading performance of 90 Iranian EFL learners. The results found that the learners having a high level of LI revealed a higher reading competence than those having a lower level of LI, while the learners with different degrees of EI showed no significant difference in their reading competence. Finally, the results indicated that LI was a strong predictor of reading comprehension.

Parsa \& Jahandar, (2013) reported that the participants who had higher verbalintelligence scores also scored higher in the vocabulary test and the participants whose score lower in verbal intelligence test had a lower score in the vocabulary test. So, it could be concluded that verbal-linguistic intelligence affected learners' knowledge of the lexicon. Skourdi \& Rahimi, (2010) conducted a research to identify the relationship between parts of Gardner's MI (that is LI and EI) and Vocabulary Learning (Receptive Breadth of Vocabulary) among Iranian EFL learners. The participants in the study were chosen from Shiraz Azad University and Shiraz State University. They were 103 junior university learners (90 females and 13 males) studying in three fields of language learning: English Language Teaching, English language Translation, and English Language Literature. They found that there was a positive and significant correlation between both of intelligence (EI and LI and vice versa), and also EI and LI on Vocabulary Knowledge. Furthermore, the result of multiple regressions analysis showed that LI was a better predictor of receptive vocabulary knowledge than EI.

Dealing with a study of emotional intelligence, Nwadinigwe \& Azuka-Obieke, (2012) studied the effect of Emotional intelligence on the academic achievement of senior high school learners in Lagos, Nigeria. One hundred fifty-six participants were randomly selected from three senior secondary schools. Questionnaire (Exploring and Developing Emotional Intelligence Skills Questionnaire) and achievement test (Mathematics, English Language, and Biology) were employed to generate data for the study. The finding showed that there was a significant positive correlation between emotional intelligence and learners' academic achievement. Maraichelvi \& Rajan (2013) investigated the relationship between MI and the academic performance among undergraduates' learners of the final year. Three hundred college teenager girls of an institute for Higher Education at Coimbatore, Tamil Nadu, India, were selected for this study. The results showed that EI could significantly predict the academic performance of college learners. Mohzan et al., (2013) reported the effect of EI on academic achievement among 278 bachelor degree learners of Education Faculty in Universiti Teknologi Mara (UiTM), Malaysia. The result revealed that there was a significant correlation between the 
respondents' overall emotional intelligence and their academic achievement, even it was found to be not statistically significant. The study of Ali, (2016) revealed that there was a correlation between academic achievement and self-emotional appraisal, regulation of emotion, use of emotions, and total emotional intelligence score. Kolachina (2016) also found that there exists a positive relationship between emotional intelligence and academic achievement among expatriate students. The study also revealed that students with high and low academic achievement motivation differ from one another on emotional intelligence. The study Sharma, (2017) showed that academic achievement has a significant effect on emotional intelligence. The other researchers, Kumar, Chowdhury, Panwar, \& Kosala, (2016) found that emotional intelligence as an independent variable was found to be highly significantly associated with the academic achievement of the nursing students. Rice (2018) supported these findings. They reported that emotional intelligence skill and higher grade point averages have a close relationship. Nia (2019) also said that between the motivation of academic achievement and quality of life and emotional intelligence have a significant relationship.

Nevertheless, two domains of EI (Self-Emotion Appraisal and Understanding of Emotion) were reported to be significantly and positively associated with the learners' academic achievement. Based on the previous findings, a few studies have conducted on the relationship between verbal-linguistic and emotional intelligence on learners' EFL academic achievement in the more specific field (in learning English only) but using all skill and knowledge (in a broader perspective) among Indonesian EFL learners.

\subsection{Methods}

\subsection{Research Design}

Based on the stated problems, the correlational research design was applied. It is because this study aims to examine possible effects or relationship among several variables (LI and EI) on the academic achievement of Indonesian EFL learners) without manipulation of a certain variable (Cohen, Manion, \& Morrison, 2007)

\subsection{Participants}

The participants of the study were 100 Indonesian EFL learners (25 males and 75 females) majoring in English Education at Universitas Kanjuruhan Malang in the sixth semester. They were selected randomly from 5 different classes based on Slovin Formula's calculation with the desired confidence level is $95 \%$ or margin error $5 \%$.

\subsection{Instruments}

The questionnaire was applied as the instrument to collect the data. It consisted of 2 sections. Section 1 was to measure learners' level of EI, and part 2 is to measure learners' level of LI. Their levels of EI were assessed by Schutte Self- Report EI Scale (SSREIS), which has been originally developed by (Schutte et al., 1998). The scale consists of 33 items with a five-point Likert scale ranging from $1=$ inappropriate to $5=$ appropriate, three of which are negatively stated. The items of SSREIS represent the following categories: 13 items were generated for assessing the appraisal and 
expression of emotion, ten items were generated for assessing the regulation of emotion and ten items were generated for determining the utilization of emotion in solving problems. The items reflected each of the components and subcomponents of each category. The total score of all the 33 items yields the total EI score of a learner. The second instrument used in this research was Niall's Linguistic Intelligence inventory which is retrieved from a Linguistic section of Multiple Intelligence Test designed based on Gardner's Multiple Intelligence theory. This inventory consists of 10 items. It has a five-point Likert scale ranging from $1=$ inappropriate to 5 = appropriate. The total score of these ten items yields the overall Linguistic Intelligence score of a learner. To validate the instrument, Schutte Self-Report Emotional Intelligence Scale and Niall's Linguistic Intelligence inventory were applied. And it showed that this instrument had good internal consistency and evidence of validity to assess the extent of an individual.

Regarding the reliability of the instruments, for Schutte Self-Report Emotional Intelligence Scale, Cronbach's alphas were reported ranging from 0.86 to 0.90, which indicates high internal consistency (Skourdi \& Rahimi, 2010; Schutte, Schuettpelz, \& Malouff, 2005; Rahimi et al., 2012). Moreover, cross-check of internal consistency replication, and Schutte et al. also conducted test-retest reliability., (2005). The results showed a Cronbach's Alpha of 0.87 for the 32 participants (for internal consistency replication) and test-retest reliability 0.78 for 28 participants (with a two-week interval between measurements). For the present study, the reliability of the scale was also calculated by Cronbach's Alpha method, yielding an index of 0.857 , which indicates that the level has high internal consistency. For the Niall's Linguistic Intelligence Inventory, Skourdi \& Rahimi, (2010) confirmed that this inventory did not have high reliability. Still, it was acceptable (Cronbach's alpha $=$ $0.559)$ due to the small number of items (10 items). It also has been confirmed by Rahimi et al., (2012), which yields an index of Cronbach's alpha $=0.55$ for using this inventory in their study. For the present study, again the reliability of the list was also calculated by Cronbach's Alpha method, yielding an index of 0.688 which indicates that the inventory did not have high reliability, but it was acceptable. To vouch that the participants would comprehend the items, the researcher has developed the scale and list by translating into the Indonesian language. After making notifications and revising the scale and inventory based on the feedback obtained, the Indonesian version of the scale and list was finalized. To measure the academic achievement of Indonesian EFL learners, the researcher collected the data by asking the respondents to voluntarily submitted their academic transcripts. The total score of the learner's assessment results of the 34 English subjects only (which on the transcript was identified by using code "ENG---") was used for this research.

\subsection{Procedure}

The entire process of data collection was done manually in a classroom. Respondents were selected for the research given a brief explanation about the purpose of the research. Then, the questionnaires (Schutte Self-Report Emotional Intelligence Scale and Niall's Linguistic Intelligence Inventory) were administered to them. They also were provided with a brief instruction on how to respond to the 5point Likert scale items to make sure they understood what was expected from them and avoid misunderstanding. The respondents were given ample time to 
complete it and asked to submit it as soon as possible they have finished. If they face any problems, the respondents were allowed to ask for clarification. At the end of this process, they were also asked to voluntarily submit their academic transcripts through social networking applications such as Facebook Messenger, other messengers or by email.

\subsection{Data Analysis}

After all of the data were obtained, scoring and consolidation of the data and processing the data was carried out. The scoring of the questionnaire response was done as the scoring scheme. The total score obtained based on the responses given by the respondents to the ten items of Niall's Linguistic Intelligence Inventory, and 33 items of SSREIS are the score of learners Linguistic and Emotional Intelligence. The responses given by the respondents were calculated as in table 1.

Table 1. Scoring of response

\begin{tabular}{ccccccc}
\hline No & $\begin{array}{c}\text { Type of } \\
\text { Items }\end{array}$ & \multicolumn{6}{c}{ Score of Response } \\
\cline { 3 - 7 } & Inappropriate & $\begin{array}{c}\text { Absolutely } \\
\text { Appropriate }\end{array}$ & Neutral & Appropriate & $\begin{array}{c}\text { Absolutely } \\
\text { Appropriate }\end{array}$ \\
\hline 1 & $\begin{array}{c}\text { Positive } \\
\text { Items } \\
\text { Negativ€ } \\
\text { Items }\end{array}$ & 5 & 2 & 3 & 4 & 5 \\
\hline
\end{tabular}

The scores obtained from the two questionnaires and also the scores of the 34 subjects taken from learners' academic transcripts were consolidated and tabulated on the consolidation sheet for analysis. Only those learners who complete the data were retained for analysis, and the data was checked double for input accuracy for computer data processing. The data then were analyzed utilizing statistical processing such as descriptive statistics, Pearson correlation, and multiple regressions by using SPSS of 24 version. The descriptive statistics were presented to portray data from the variables accurately. The effect of each independent variable to the dependent variable (learners' Emotional Intelligence and learners' academic achievement, learners' Linguistic Intelligence and learners' academic achievement) were tested through Pearson product-moment correlation to answer the first two questions. Furthermore, to answer the third question whether any simultaneous effect between the two independent variables on the dependent variable and also which one of the variables (LI or EI) is a better predictor of learners' academic achievement in learning English, multiple regressions were applied.

\section{Results}

After all the data collected, the researcher then tabulated the data for further analysis. From a 100-data collected, only 78 data were qualified for analysis because there were some learners did not take several subjects which were required by the researcher to measure their academic achievement. Besides, some learners have taken the subjects required, but the score they got was zero. So, the researcher also eliminated the data. The respondents were given ten items of Niall's Linguistic Intelligence Inventory and the 33 elements of SERIES. The 
researcher take scores of learners' academic transcript 34 subjects taken from 1 . The following table presents the descriptive statistics of the variables that were being studied based on the score obtained.

Table 2. Descriptive Statistics

\begin{tabular}{|c|c|c|c|c|c|}
\hline & $\mathrm{N}$ & Min & $\operatorname{Max}$ & Mean & SD \\
\hline Linguistics & 78 & 23 & 44 & 34.86 & 4.589 \\
\hline Intelligence & & & & & \\
\hline $\begin{array}{l}\text { Emotion } \\
\text { Intelligence }\end{array}$ & 78 & 92 & 154 & $125 . .08$ & 12.271 \\
\hline $\begin{array}{l}\text { Academic } \\
\text { Achievement }\end{array}$ & 78 & 3.00 & 3.94 & 3.4758 & .9402 \\
\hline
\end{tabular}

Before the hypothesis testing was carried out, the data was tested for its normality, linearity, multicollinearity, and heteroscedasticity as a prerequisite of the hypothesis testing of parametric statistics analysis. The results showed that all the data had a normal distribution, the two independent variables had a linear relationship with the dependent variable, there was no multicollinearity problem between the independent variables, and also there was no problem of heteroscedasticity of both independent variables in the regression model.

4.1 Correlation Between LI, EI and Academic Achievement of Indonesian EFL Learners.

To find out the effect of every independent on the dependent variables (learners' LI on learners' academic achievement, learners' EI on the academic achievement of Indonesian EFL learners), Pearson correlation analysis was carried out. The detailed finding will be explained in the table as follow:

Table 3. Correlation Between LI, EI and Academic Achievement

\begin{tabular}{llccc}
\hline & & $\begin{array}{c}\text { Linguistic } \\
\text { Intelligence } \\
(\mathrm{LI})\end{array}$ & $\begin{array}{c}\text { Emotional } \\
\text { Intelligence } \\
(\mathrm{EI})\end{array}$ & $\begin{array}{c}\text { Academic } \\
\text { Achievement }\end{array}$ \\
\hline $\begin{array}{l}\text { Linguistic } \\
\text { Intelligence }\end{array}$ & Pearson & 1 & .585 & .662 \\
& Correlation & & & .000 \\
& Sig. (2-tailed) & $\mathrm{N}$ & 78 & 78 \\
Emotional & Pearson & .585 & 1 & .353 \\
Intelligence & Correlation & & & .002 \\
& Sig. (2-tailed) & .000 & 78 & 78 \\
& $\mathrm{~N}$ & 78 & .353 & 1 \\
Academic & Pearson & .662 & & \\
Achievement & Correlation & & .002 & 78 \\
& Sig. (2-tailed) & .000 & 78 & \\
& $\mathrm{~N}$ & 78 & & \\
\hline
\end{tabular}

As presented in table 3, the correlation coefficient $(r)$ obtained from the analysis for LI and academic achievement was 0.662 with the Sig-value $(p)$ was 0.000 . It meant that there was a positive, strong effect of learners' LI on their academic achievement in learning English. This effect was found to be statistically significant $(p=0.000<0.05)$. Meanwhile, the correlation coefficient $(r)$ for EI and academic achievement was 0.353 with the Sig-value $(p)$ was 0.002 . It meant that 
there was a weak positive effect of learners' EI on their academic achievement in learning English. This effect was also found to be statistically significant ( $p=$ $0.002<0.05$ ). Thus, both of the first and the second null hypothesis, that was, there was no effect of learners' LI on the academic achievement of Indonesian EFL learners and there was no effect of learners' EI on the academic achievement of Indonesian EFL learners were rejected so that the alternate hypothesis was accepted. It meant that both of the independent variables (learners' LI and learners' EI) had a significant effect on the academic achievement of Indonesian EFL learners, even though learners' EI tent to show a weaker effect on academic achievement than their Linguistic Intelligence.

\subsection{The Simultaneous Effect of LI and EI on the Academic Achievement of Indonesian EFL Learners.}

To find out the simultaneous effect of the two bits of intelligence (LI and EI) on the academic achievement of Indonesian EFL learners, the extent of those effects affects academic achievement, and also to determine the better predictor of learners' academic achievement and the multiple regression equations. Multiple Regression analysis was carried out. The following tables present the overall result of the analysis.

Table 4. Model Summary

\begin{tabular}{ccccc}
\hline Mode & $\mathrm{R}$ & $\begin{array}{c}\mathrm{R} \\
\text { Square }\end{array}$ & $\begin{array}{c}\text { Adjusted R } \\
\text { Square }\end{array}$ & $\begin{array}{r}\text { Std. Error } \\
\text { of Estimat }\end{array}$ \\
\hline 1 & .663 & .440 & .425 & .14714 \\
\hline
\end{tabular}

Table 4 showed that the multiple coefficients correlation (R) obtained from the analysis, as presented in the above data was 0.663 . The value of R-square was .440 . It means that the percentage contribution of the effect LI and EI on academic achievement simultaneously was $44 \%$. It meant that $44 \%$ variable of the academic achievement was affected by LI and EI, while the remaining $56 \%$ was affected by other variables.

Table 5. Analysis of Variance (ANOVA)

\begin{tabular}{ccccccc}
\hline Model & & $\begin{array}{c}\text { Sum of } \\
\text { Squares }\end{array}$ & $\mathrm{df}$ & $\begin{array}{c}\text { Man } \\
\text { Square }\end{array}$ & $\mathrm{F}$ & Sig. \\
\hline \multirow{2}{*}{1} & Regressio1 & 1 & 2 & .637 & 29.446 & .000 \\
& Residual & 1.624 & 75 & .022 & & \\
& Total & 2.899 & 77 & & & \\
\hline
\end{tabular}

Table 5 showed that $\mathrm{F}=29.446$ with $\mathrm{P}=.000<.05$. It meant that the null hypothesis stated that there was no effect between LI and EI on academic achievement was rejected. It can be concluded that there was an interaction between $\mathrm{Li}$ and $\mathrm{EI}$ on the academic achievement of Indonesian EFL learners. 
Table 6. Coefficients Correlation

\begin{tabular}{|c|c|c|c|c|c|c|}
\hline & Model & $\begin{array}{l}\text { Unstandardizer } \\
\text { Coefficients }\end{array}$ & & $\begin{array}{c}\text { Standardized } \\
\text { Coefficients }\end{array}$ & $\mathrm{t}$ & Sig. \\
\hline & & B & Std. Error & Beta & & \\
\hline 1 & (Constant) & 2.559 & .175 & & $14.62 \prime$ & .000 \\
\hline & $\begin{array}{l}\text { Linguistic } \\
\text { Intelligenc }\end{array}$ & .029 & .005 & .693 & 6.498 & .000 \\
\hline & $\begin{array}{l}\text { Emotional } \\
\text { Intelligenc }\end{array}$ & .000 & .002 & .053 & .494 & .623 \\
\hline
\end{tabular}

Based on table 6 , the regression coefficient of LI $\left(b_{1}\right)$ was 0.029 and the regression coefficient of EI $\left(b_{2}\right)$ is 0.000 , while the constant value of $a=2.559$. So, it can be concluded that LI was a better predictor of academic achievement of Indonesian EFL learners, while the multiple regression equations were as follows:

$\mathrm{Y}^{\prime}=a+b_{1} \mathrm{X}_{1}+b_{2} \mathrm{X}_{2}$

$\mathrm{Y}^{\prime}=2.559+0.029^{*} \mathrm{X}_{1}+0.000^{*} \mathrm{X}_{2}$

$Y^{\prime}=2.559+0.029 * X_{1}$

Student's academic achievement $=2.559+0.029 *$ learners' LI

From the multiple regressions equation above can be explained that the constant value of multiple regressions model was 2.559. It means that if the score of LI and EI were 0 , the score of the academic achievement of Indonesian EFL learners was 2.559. Then, the regression coefficient of LI $\left(b_{1}\right)$ was 0.029 . It means that in every point of increase in LI score $\left(X_{1}\right)$, the academic achievement $\left(Y^{\prime}\right)$ will increase by 0.029. The coefficient was positive means there was a positive relationship between LI and the academic achievement, the rise of LI increasing the academic achievement. For the regression coefficient of EI $\left(b_{2}\right)$, because the value was 0.000 , which means that this coefficient did not give an impact on the academic achievement, so it was removed.

The results of hypothesis testing with Pearson product-moment correlation revealed that there was a positive and significant correlation between LI and academic achievement of Indonesian EFL learners. The level of relationship between the variables was found statistically strong with the correlation coefficient $(r)$ obtained from the analysis was 0.662. This effect was also found to be statistically significant with the Sig-value $(p)$ was 0.000 , which means it was very meaningful at 0.05 level of significance. So, it proved that LI truly had a significant effect on academic achievement. The higher their level of Linguistic Intelligence, the better they perform academically in learning English.

\subsection{Discussion}

As mentioned above, LI is involved in the ability to manipulate structure (Syntax), sound (Phonology), meaning (Semantics), practical uses of language (Pragmatics), and also using language to convince others to take a specific course of action (rhetoric), using language to remember information (mnemonics), using language to inform (explanation), and using language to talk about itself (meta-language) (Armstrong, 2009). So, the individual with high LI can achieve a higher level of second or foreign language (L2) proficiency than the individual with low LI. It 
means that in terms of mastery of a new language (English), individual with high LI also likely has a higher capacity than the individual with low LI.

Many previous studies also indicate the same results. The findings have reported that LI as a part of MI correlates with learners' English performance or their English skills in more specific such as reading, speaking, listening, etc., and language knowledge such as vocabulary or understanding of lexicon, etc. The study conducted by (Hou, n.d.)on 2545 Taiwanese college learners to explore the role of Multiple Intelligences (MI) in foreign language learning behaviour and performance indicated that verbal/linguistic intelligence had correlation and was also good predictors of English performance. The results of this study also confirmed by many other studies such as the study conducted by Skourdi \& Rahimi, (2010) that showed a positive and significant relationship between Linguistic intelligence and vocabulary learning, Parsa \& Jahandar, (2013) also indicated that verbal-linguistic intelligence affects learners' knowledge of lexicon, Rahimi et al., (2012) which stated that the learners with a high level of linguistic intelligence showed a higher reading ability than those with a lower level of linguistic intelligence, the study conducted by Saibani \& Simin, (2014) which indicated that verbal intelligence is the main predictors of speaking ability, etc. Although the variables used in the above studies were not the same with this study, all of the results of those studies again confirmed that Linguistic intelligence had a significant effect on learners' success in learning English.

Meanwhile, the results of second hypothesis testing that also analyzed with Pearson product-moment correlation indicated that there was a significant correlation between Emotional Intelligence and academic achievement in learning English. The level of relationship between the variables was found statistically weak with the correlation coefficient $(r)$ obtained from the analysis was only 0.353. But this effect was also found to be statistically significant with the Sig-value $(p)$ was 0.002 , which means it was very meaningful at 0.05 level of significance. So, it also proved that Emotional Intelligence also had a significant effect on learners' academic achievement in learning English. The higher their level of EI, the better they perform academically in learning English.

Goleman's theory states that a person with high emotional intelligence will be able to motivate himself and persist in the face of frustration, be able to control impulse and delay gratification, be able to regulate his moods and keep distressed from swamping the ability to think and be able to empathize and hope. So, in this case, learners which were emotionally smart will have more capacity to understand their intentions and motivations, to solve problems, to work effectively with others, etc, which however will positively affect the process of learning that was conducted with many other learners like in a formal educational institution (schools or universities).

Many previous studies also indicated that Emotional intelligence has a significant correlation with academic achievement. A study conducted by Nwadinigwe \& Obieke (2012) reported that academic achievement was influenced by emotional intelligence skills. It's also supported by Maraichelvi \& Rajan (2013) found that 
there was a close relationship between Emotional Intelligence and academic performance. Moreover, the study of Mohzan et al. (2013) revealed that there was a positive relationship between the respondents' overall emotional intelligence and their academic achievement.

Despite, the level of correlation between Emotional intelligence and academic achievement of this study was found statistically weak, however, it was a positive significant correlation, which means that the Emotional intelligence still give a positive impact on academic achievement of EFL learners and can be generalized to the population, even though it was not as high as the impact provided by linguistic intelligence.

EI tent to show a weaker effect on learners' academic achievement of EFL learner in learning English than their Linguistic Intelligence was due to the Emotional Intelligence in this case certainly had a less role. As stated by Rahimi et al. (2012) that linguistic intelligence has more to do with cognition (which is an essential process incomprehension) than Emotional intelligence. It is a matter of personality trait. In this case, the process of comprehension or to do something with cognition is more dominant in learning the 34 subjects which were used to measure learners' academic achievement than the use or to do something with emotion. It was different from learning the literary works or drama only which was the emotions play an important role in the success of learning because sometimes it was emotionally loaded and challenge the general Emotional Intelligence of the learners (Rahimi et al., 2012). The last, the result of the third hypothesis testing that analyzed by multiple regression analysis also indicated that there was the significant positive correlation between the two independent variables (LI and EI) simultaneously on the dependent variable (learners' academic achievement) in learning English. This result can be ensured because each of the dependent variables partially had a significant positive correlation with the dependent variable, as explained in the previous discussion. The level of relationship between the two independent variables and the dependent variable was found statistically substantial with the multiple correlation coefficients (R) obtained from the analysis was 0.663 . This effect was also found to be statistically significant with the Sigvalue $(p)$ was 0.000 , which means it was very meaningful at 0.05 level of significance. It proved that linguistic Intelligence and emotional intelligence simultaneously had a significant effect on the academic achievement of Indonesian EFL learners. The higher their level of Linguistic and Emotional Intelligence, the better they perform academically in learning English.

Furthermore, the value of R-square obtained from the analysis was 0.440. It means that LI and EI in this study gave a $44 \%$ effect of learners' academic achievement in learning English, a great enough number of contributions that can be taken into consideration for the language instructor to help their learners to improve their academic achievement in learning English. Moreover, still based on the multiple regression analysis had explained in the previous subtitle, only linguistic intelligence can be used to predict academic achievement. While the Emotional intelligence, it can't be used to predict academic achievement because the value of the regression coefficient was 0.000 which means that this coefficient will not give 
an impact on the academic achievement, so it was removed. It may because the level of relationship between the two variables partially was statistically weak (0.353), not as the level of relationship between Linguistic intelligence and learners' academic achievement that statistically strong (0.662), so, it can be used to portend the value of learners' academic achievement in learning English.

All the results of this study proved that the researcher's assumptions had been stated in the above; that is the LI and EI affect learners' success in learning L2 is true. A pedagogical implication can be suggested i.e. the language instructors (teachers and lecturers) may use the results of this study as a consideration in planning classroom activities or teaching and learning processes in general to improve learners' academic achievement in learning English or their success in learning EFL.

\section{Conclusion}

Based on the research findings and discussions, it can be concluded that there was a positive and significant effect of learners' LI on learners' academic achievement in learning English with the correlation coefficient $r=0.662$. So, the higher their level of LI, the better they perform academically. And there was a positive and significant effect of learners' EI on learners' academic achievement in learning English with the correlation coefficient $r=0.353$. So, the higher their level of Emotional Intelligence, the better they perform academically.

Dealing with simultaneously effect between LI and EI on learners' academic achievement of EFL learners showed that the correlation coefficient $R=0.663$. So, the higher their level of LI and EI, the better they perform academically. The percentage contribution of effect given by LI and EI simultaneously on learners' academic achievement was $44 \%$ or it can be said that $44 \%$ variance of learners' academic achievement in learning English was explained or affected by LI and EI, while the remaining $56 \%$ was explained or affected by other variables not included in this study. The findings of this study were limited by 'two what extent LI and EI influenced simultaneously on academic achievement. The findings recommended that LI was a better predictor of learners' academic achievement in learning English for EFL learners.

\section{References}

Abbassi, A., Hassaskhah, J., \& Tahriri, A. (2018). The Effect of Teaching Memory Strategies on Iranian EFL Learner's Vocabulary Retention in Terms of learners' Multiple Intelligences. International Journal of Education and Literacy Studies, 6(2), 1. https://doi.org/10.7575/aiac.ijels.v.6n.2p.1

Andreani, W. (2017). Emotional Intelligence, Self-Esteem and Academic Achievement: A Case Study, English Department Students. Humaniora, 3(1), 98. https://doi.org/10.21512/humaniora.v3i1.3239

Armstrong, T. (2009). Intelligences multiple in the classroom. Educational Research, 18. https:// doi.org/10.3102/0013189X018008004

Berenji, S. (2010). The Relationship between Emotional Intelligence and Students` Academic Achievements in General EFL Classes. The Journal of Applied 
Linguistics, 3(2).

Choerudin, A. (2017). The Effect of Emotional Intelligence on Job Performance and Turnover Intention: an Empirical Study. Polish Journal of Management Studies, 14(1), 51-62. https://doi.org/10.17512/ pjms.2016.14.1.05

Cohen, L., Manion, L., \& Morrison, K. (2007). Research Methods in Education. New York: Routledge 270 Madison Avenue. https:/ / doi.org/10.4135/9781849209045

Gardner, H. (1987). The theory of multiple intelligences. Annals of Dyslexia, 37(1), 19-35. https://doi.org/10.1007/BF02648057

Gharetepeh, A., Safari, Y., Pashaei, T., Razaei, M., \& Bagher Kajbaf, M. (2015). Emotional intelligence as a predictor of self-efficacy among students with different levels of academic achievement at Kermanshah University of Medical Sciences. Journal of Advances in Medical Education \& Professionalism, 3(2), 50-55. Retrieved from http://www.ncbi.nlm.nih.gov/pubmed/25927067\%0Ahttp://www.pubmedce ntral.nih.gov/articlerender.fcgi?artid=PMC4403564

Halil, N. I. (2017). The Actualization of Literary Learning Model Based on VerbalLinguistic Intelligence. International Journal of Education and Literacy Studies, 5(4), 42. https://doi.org/10.7575/aiac.ijels.v.5n.4p.42

Hou, Y. (n.d.). Multiple Intelligences and Foreign Language Learning. A Case Study of Taiwanese Learners of English and Japanese, 2012.

Kang, F. (2015). Contribution of Emotional Intelligence towards Graduate Students' Critical Thinking Disposition. International Journal of Education and Literacy Studies, 3(4), 6-17. https://doi.org/10.7575/aiac.ijels.v.3n.4p.6

Kachina, A. (2016). Impact of Emotional Intelligence on Academic Achievements of Expatriate College Students in Dubai. Journal of Psychiatric Nursing, 2(2), 23-26. https://doi.org/10.21088/jpn.2277.9035.4115.4

Kuh, G. D., Kinzie, J., Buckley, J. A., Bridges, B. K., \& Hayek, J. C. (2006). What matters to student success: a review of the literature. Commissioned Report for the National Symposium on Postsecondary Student Success: Spearheading a Dialog on Student Success. National Postsecondary Education Cooperative (July), 156. https:// doi.org/10.1111/ijs.12356

Kumar, A., Chowdhury, S. K. R., Panwar, M., \& Kosala, M. (2016). Assessment of Association between Emotional Intelligence and Academic Achievement among Indian Nursing Students, 1(December), 10-17.

Maraichelvi, A., \& Rajan, S. (2013). The Relationship between Emotional Intelligence and the Academic Performance among Final Year under Graduates. Universal Journal of Psychology, 1(2), 41-45. https://doi.org/10.13189/ujp.2013.010203

Mohzan, M. A. M., Hassan, N., \& Halil, N. A. (2013). The Influence of Emotional Intelligence on Academic Achievement. Procedia - Social and Behavioral Sciences, 90 (InCULT 2012), 303-312. https:// doi.org/10.1016/j.sbspro.2013.07.095

Mustafa Ali Khalaf Ali. (2016). The Relationship between Emotional Intelligence and Academic Achievements in Males and Females in Egyptian Context. Journal of Psychology Research, 6(10), 567-578. https:// doi.org/10.17265/2159$5542 / 2016.10 .002$

Nia, R. G. (2019). Investigate the relationship between academic achievement and emotional intelligence and quality of life in Bam University of Medical sciences2015. Women's Health, 7(2), 48-51. https:// doi.org/10.15406/mojwh.2018.07.00166

Nwadinigwe, I., \& Azuka-Obieke, U. (2012). The Impact of Emotional Intelligence on Academic Achievement of Senior Secondary School Students in Lagos, Nigeria. Journal of Emerging Trends in Educational Research and Policy Studies, 3(4), 395-401.

Parsa, M., \& Jahandar, S. (2013a). The Effect of Verbal Intelligence on Knowledge of 
Lexicon. International Journal of Applied Linguistics \& English Literature, 2(2), 114121. https://doi.org/10.7575/aiac.ijalel.v.2n.2p.114

Parsa, M., \& Jahandar, S. (2013b). The Effect of Verbal Intelligence on Knowledge of Lexicon. International Journal of Applied Linguistics \& English Literature, 2(2), 114121. https://doi.org/10.7575/aiac.ijalel.v.2n.2p.114

Pathak, N., Tiwari, J. R., Patel, N., \& Kendra, K. V. (2018). A Study on Association between Adjustment and Academic Achievement of Adolescent Studying in Different Types of Educational Boards, 7(2), 691-695. https://doi.org/10.21275/ART20179960

Rahimi, A. (2014). The relationship of Emotional Intelligence and Linguistic Intelligence in acquiring vocabulary Sedigheh Skourdi Islamic Azad University, Bandar Abbas Branch, Iran Ali Rahimi University of Kashan, Iran The relationship of Emotional Intelligence and Ling, (September).

Rahimi, M., Sadighi, F., \& Hosseiny Fard, Z. (2012). The impact of linguistic and emotional intelligence on the reading performance of Iranian EFL learners. Journal of Teaching Language Skills, 30(1), 151-171.

Rice, D. M. (2018). The relationship of emotional intelligence to academic achievement. National Teacher Education Journal, 11(1), 27-33. Retrieved from http:/ / search.ebscohost.com/login.aspx?direct=true\&AuthType=sso\&db=eue\& $\mathrm{AN}=131494011 \&$ site $=$ eds-live\&scope $=$ site\&authtype $=$ sso\&custid $=$ ns083389

Saibani, B., \& Simin, S. (2014). The relationship between multiple intelligences and speaking skill among intermediate EFL learners in Bandar Abbas Azad University in Iran. International Journal of Research Studies in Language Learning, 4(2), 43-56. https://doi.org/10.5861/ijrsll.2014.861

Schutte, N. S., Malouff, J. M., Hall, L. E., Haggerty, D. J., Cooper, J. T., Golden, C. J., \& Dornheim, L. (1998). Individual EI, 25, 167-177. https://doi.org/10.1016/S01918869(98)00001-4

Schutte, N. S., Schuettpelz, E., \& Malouff, J. M. (2005). Emotional Intelligence and Task Performance. Imagination, Cognition and Personality, 20(4), 347-354. https://doi.org/10.2190/j0x6-bhtg-kpv6-2uxx

Sharma, A. (2017). A study of Emotional Intelligence in Relation to Academic Achievement, Gender and Locality. International Journal of Engineering Technology Science and Research, 4(7), 2017. Retrieved from www.ijetsr.com

Shero M. Z. S., Allo, A. A. H., \& Mohammedzadeh, B. (2018). Multiple Intelligences Based Planning of EFL Classes. Advances in Language and Literary Studies, 9(2), 98. https://doi.org/10.7575/aiac.alls.v.9n.2p.98

Skourdi, S., \& Rahimi, A. (2010). Sedigheh Skourdi Ali Rahimi The relationship of Emotional Intelligence and Linguistic Intelligence in acquiring vocabulary. California Linguistic Notes, XXXV(1), 1-24.

Tabatabaei, O., \& Jamshidifar, M. (2013). The Relationship between Emotional Intelligence and Willingness to Communicate among EFL Learners. International Journal of English Language Education, 2(1), 90. https://doi.org/10.5296/ijele.v2i1.4650

Vincey, D. (2016). A Study of Linguistic Intelligence and Academic Achievement of the Student At Standard Xi Level, 4(4), 25-31. 